\title{
WORONIN BODIES IN PENICILLIUM JANCZEWSKII ZALESKI
}

\author{
Rosemeire A.B. Pessoni ${ }^{1}$; Glenn Freshour ${ }^{2}$; Rita de Cássia L. Figueiredo-Ribeiro ${ }^{3}$; Michael G. Hahn² ${ }^{2}$ Márcia R. Braga $^{3 *}$ \\ ${ }^{1}$ Universidade Metodista de São Paulo, São Bernardo do Campo, SP, Brasil. ${ }^{2}$ University of Georgia, Athens, GA, USA. ${ }^{3}$ Seção \\ de Fisiologia e Bioquímica de Plantas, Instituto de Botânica, São Paulo, SP, Brasil.
}

Submitted: February 18, 2002, Approved: June 10, 20002

\begin{abstract}
Penicillium janczewskii Zaleski is an efficient microorganism for the production of extracellular inulinases and grows rapidly on medium containing sucrose or inulin as carbon source. Maintenance of this filamentous fungus on inulin medium induces secretion of large amounts of inulinases, but the resulting mycelium has thinner cell walls that easily collapse and break. Woronin bodies in hyphae of $P$. janczewskii grown on sucrose and inulin substrates were observed. No significant differences in the number, location, size and shape of Woronin bodies and level of plugging were observed in cultures of the fungus grown on the two carbon sources. The data indicate that the presence of Woronin bodies in P. janczewskii could not be associated with more easily damaged hyphae, although the function of these organelles in pore plugging has been confirmed.
\end{abstract}

Key words: Woronin bodies, Penicilliun, inulin, sucrose.

\section{INTRODUCTION}

Woronin bodies are cellular organelles of filamentous fungus that were first described in the Ascomycetes by the Russian mycologist Michael Stepanovich Woronin (4). Although the precise function of the Woronin bodies has not yet been determined, recent results suggest that they represent a new category of peroxissomes engaged in the maintenance of cellular integrity (3). In intact hyphae, the Woronin bodies seem to be unaffected by normal intercellular cytoplasmic streaming, being attached to the plasma membrane. However, when hyphae lyse, the release of cellular turgor triggers an instant increase in the rate of cytoplasmic flow, and this change dislodges Woronin bodies from their site of attachment to the plasma membrane. These corpuscles then rapidly occlude the septal pore after lysis, sealing them and thereby preventing catastrophic cell death (3).

Penicillium janczewskii, a filamentous fungus isolated from the rhizosphere of Vernonia herbacea (Vell.) Rusby (Asteraceae) grows rapidly on media containing either sucrose or inulin as the sole carbon source (2). When grown on inulin, this fungus is considered an efficient microorganism for the industrial production of extracellular inulinases due to the high yield and specific activity of the enzymes secreted into the culture medium (7). These inulinases can be utilised in industry for the preparation of fructose syrups from inulin (6).

Differences in cell walls thickness and in colony pigmentation of $P$. janczewskii have been found depending on whether this fungus is cultivated in media containing sucrose or inulin. Maintenance of the fungus on inulin medium results in thinner mycelia that easily collapse and break, as observed during preparation of fungal material for scanning-electron microscopy (Fig. 1A).

In the present work we looked for the presence of Woronin bodies in hyphae of the Penicillium janczewskii grown on sucrose and inulin substrates.

\section{MATERIALS AND METHODS}

\section{Microorganism}

Penicillium janczewskii Zaleski (URM 3511 - Universidade Federal de Pernambuco- Recife, Brazil) was isolated from the rhizosphere of Vernonia herbacea (Vell.) Rusby,

\footnotetext{
* Corresponding author. Mailing address: Seção de Fisiologia e Bioquímica de Plantas, Instituto de Botânica, Caixa Postal 4005. 01061-970, São Paulo,
} SP, Brasil. Phone: (+5511) 5073-6300 Ext. 289, Fax: (+5511) 5073-3678. E-mail: bragamr@canalvip.com.br 
Asteraceae, growing naturally in a cerrado area near Moji-Guaçu (SP, Brazil) (2).

\section{Culturing}

The fungus was grown on solid medium containing the following components $\left(\mathrm{g} . \mathrm{l}^{-1}\right)$ : $\mathrm{NaNO}_{3}(3), \mathrm{KH}_{2} \mathrm{PO}_{4}(1), \mathrm{KCl}(0.5)$, $\mathrm{MgSO}_{4} .7 \mathrm{H}_{2} \mathrm{O}(0.5), \mathrm{FeSO}_{4} .7 \mathrm{H}_{2} \mathrm{O}(0.01)$, agar $(1.5 \%$, w/v) and either inulin $(1 \%, \mathrm{w} / \mathrm{v})$ from Helianthus tuberosus (Sigma) or sucrose $(1 \%, \mathrm{w} / \mathrm{v})$ as sole carbon sources. Cultures were incubated at $28^{\circ} \mathrm{C}$ for $5-8$ days in darkness.

\section{Transmission electron microscopy (TEM)}

A $1 \mathrm{~mm}^{3}$ plug was cut from the actively growing margin of the colony of each fungal culture using a razor blade and initially fixed at room temperature in a solution containing $2.5 \%(\mathrm{v} / \mathrm{v})$ glutaraldehyde, $2.5 \%(\mathrm{v} / \mathrm{v})$ paraformaldehyde and

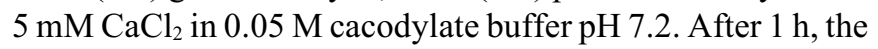
material was washed with three changes (10 min each) of the same buffer and postfixed for $1 \mathrm{~h}$ in $0.05 \mathrm{M}$ cacodylate buffer supplemented with $5 \mathrm{mM} \mathrm{CaCl}_{2}$ and containing $1 \%(\mathrm{w} / \mathrm{v}) \mathrm{OsO}_{4}$. Subsequently, the fixed material was transferred to $1 \%(\mathrm{w} / \mathrm{v})$ uranyl acetate and was left in this solution overnight. Samples were dehydrated with a graded aqueous acetone series $(30$, $50,70,90,100,100,100 \%[\mathrm{v} / \mathrm{v}] ; 10 \mathrm{~min}$ each step). The dehydrated material was first infiltrated with Spurr's resin in $1 \%(\mathrm{w} / \mathrm{v})$ uranyl acetate $(1: 1)$ for $5 \mathrm{~h}$, and then in pure Spurr's resin overnight. The infiltrated tissue was transferred to templates containing 100\% Spurr's resin. Polymerisation was carried out at $60^{\circ} \mathrm{C}$ for $24 \mathrm{~h}$.

Thin sections $(<100 \mathrm{~nm})$ were cut with an MT $6000-\mathrm{XL}$ ultramicrotome and collected on Formvar-coated, gilded copper slots grids and placed on Formvar bridges to dry (9). The sections were poststained for $30 \mathrm{~s}$ with $2 \%(\mathrm{w} / \mathrm{v})$ lead citrate (8). The sections were examined at $80 \mathrm{kV}$ with a Zeiss EM 902A electron microscope.

\section{Statistics}

Measurements of the outside diameter of the Woronin bodies were performed only on those organelles in which the outer membrane was clearly visible, in order to insure that the plane section caught them through or near the centre. At least 80 measurements of Woronin bodies were recorded for fungal cultures grown on each substrate. The means were compared by Student's test at $95 \%$ confidence level.

\section{RESULTS AND DISCUSSION}

Woronin bodies were shown to be present in hyphae of Penicillium janczewskii grown for 5-8 days on both sucrose (Figs. 2A, B) and inulin (Fig. 2C). No substantial differences were observed in the location, number, size and shape of the Woronin bodies observed in hyphae grown on media containing the two
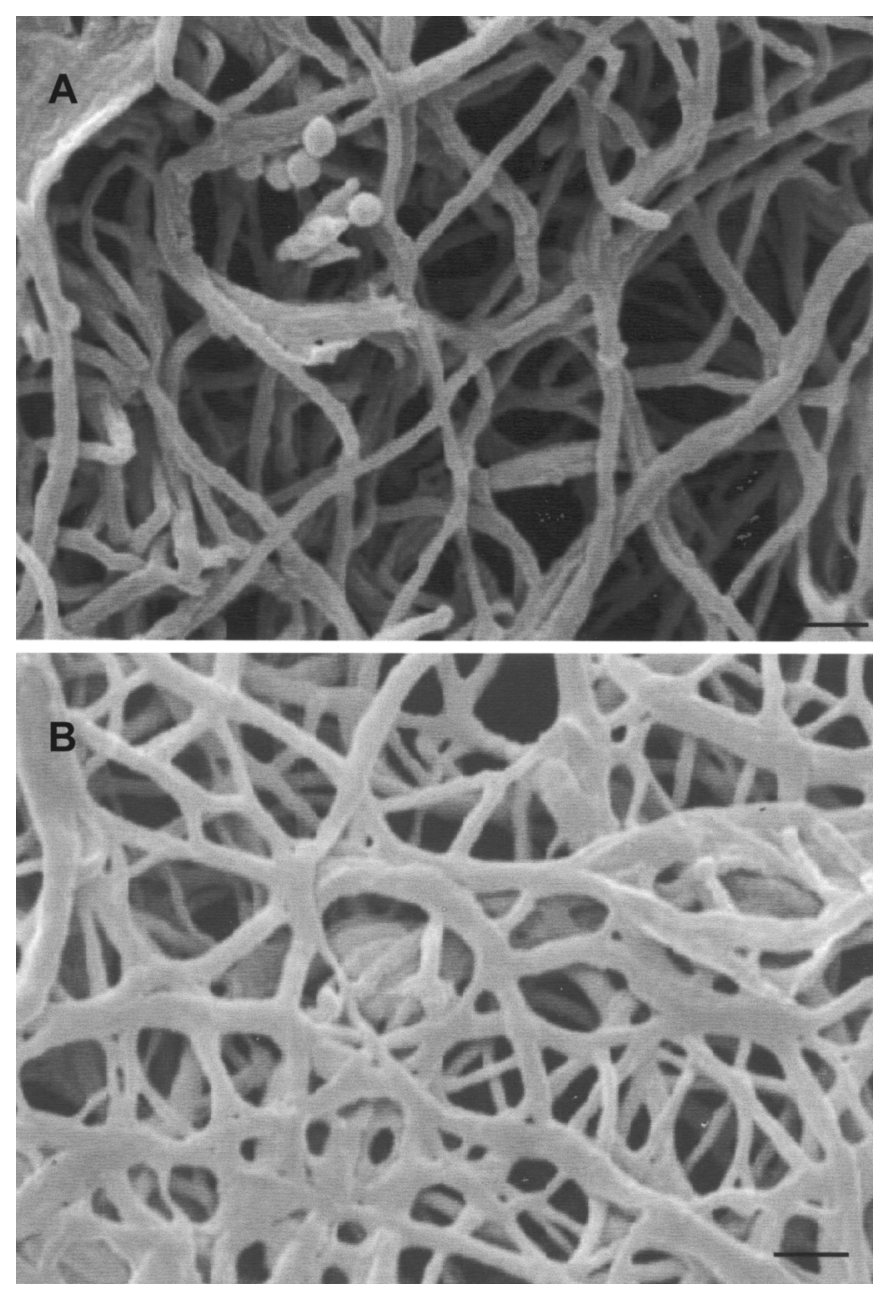

Figure 1. Scanning electron microscopy of Penicillium janczewskii hyphae grown on inulin (A) (X 6380) and sucrose (B) (X 5560), bar $=3 \mu \mathrm{m}$.

different carbon sources (Figs. 2B, C). As shown in Fig. 2, Woronin bodies of $P$. janczewskii are spherical, have irregular edges, are often within a well-defined membrane (Fig. 2B) and are variable in size. Two to four Woronin bodies could generally be observed in the zones close to the septum (Fig. 2A). Woronin bodies were generally observed to be located on both sides of the septa (Figs. 2A, D), and sometimes crossing the central pore (Figs. 2D, E). They ranged in diameter from 102 to $129 \mathrm{~nm}$, the average being $116 \pm 9$ (SD), and were larger than the average diameter of septal pores (ca. $70 \mathrm{~nm}$ ). Collinge and Markham (1) reported the presence of Woronin bodies of $167 \pm 8 \mathrm{~nm}$ diameter in mycelia of Penicillium chrysogenum, larger than those observed here in P. janczewski. Woronin bodies have also been observed in many other fungal species, including those belonging to the genus Arthrinium (4) and in Disciotis venosa (10), where they appear spherical and hexagonal in shape, respectively. 


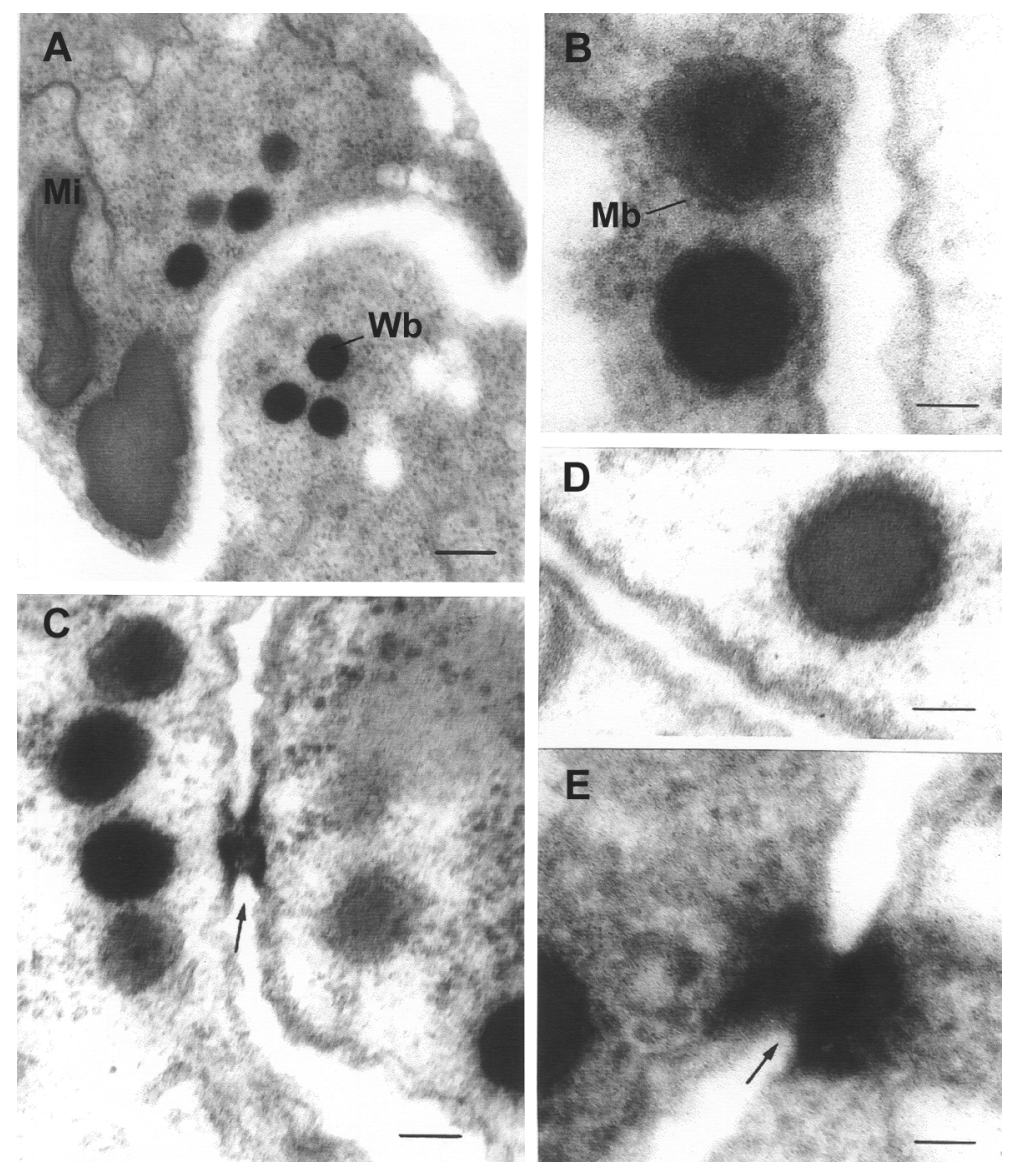

Figure 2. Woronin bodies (Wb) in Penicillium janczewskii hyphae grown on sucrose (A, B, D, E) and on inulin (C). (A) - Woronin bodies in both sides of the septum (X 22000), bar $=0.3 \mu \mathrm{m}, \mathrm{Mi}=$ mitochondria. $(\mathbf{B})$ and (D) - Spherical Woronin bodies showing the irregular edge and the surrounding membrane $(\mathrm{Mb})(\mathrm{X} 90000), \mathrm{bar}=0.08 \mu \mathrm{m}$. (C) View of a pore plugged by the Woronin body (arrow) (X 52000), bar $=0.14 \mathrm{~mm}$. (E) Detail of the pore plugging (X 90000), bar $=0.08 \mu \mathrm{m}$.

The plugging of septal pores by Woronin bodies has consistently been observed at very high levels in damaged mycelia when compared to undamaged actively growing hyphae, suggesting that a major function of this organelle is the emergency plugging of septal pores in response to severe hyphal damage that breaches the hyphal wall (5). For example, pore plugging by Woronin bodies in $P$. chrysogenum was demonstrated to be a rapid and specific response to the induced severing of hyphae (1).

In P. janczewskii, hyphae from fungus grown on inulincontaining medium were much thinner than those cultivated on sucrose (Figs. 1A, B), and presenting significant differences in the cell wall thickness, being more easily damaged. Transmission electron microscopy of 5-day-old cultures indicated that the cell wall thickness is around $384 \pm 90($ mean $\pm \mathrm{SD})$ and $800 \pm 20 \mathrm{~nm}$ for hyphae grown on inulin and sucrose media, respectively. More Woronin bodies or higher level of pore plugging thereby would be expected to be present in hyphae grown on inulin. However, no significant differences in the number of Woronin and level of plugging were observed in cultures of $P$. janczewskii grown on the two carbon sources. Our data indicate that, at least in P. janczewskii, the presence of Woronin bodies could not be associated with more easily damaged hyphae, although the function of these organelles in pore plugging has been confirmed. These findings indicate that more work is necessary in order to bring conclusive evidence of the exact correlation between the level of pore plugging by Woronin bodies and damage control during fungal growth.

\section{ACKNOWLEDGEMENTS}

The authors thank Dr. E.W. Kitajima and Dr. B. Leite from NAP/MEPA (ESALQ/USP, Brazil) for helping with fixation and embedding procedures, and M.C. Tomasi for assistance with the figure. This work was supported by FAPESP (98/05124-8).

\section{RESUMO}

\section{Corpúsculos de woronin em Penicillium janczewskii Zaleski}

Penicillium janczewskii Zaleski é um microrganismo eficiente para a produção de inulisases extracelulares e cresce rapidamente em meio contendo sagarose ou inulina como fonte de carbono. A manutenção desse fungo filamentoso em meio com inulina induz a secreção de grandes quantidades de inulisanes, mas resulta na presença de um micélio com parede celulares mais finas, que facilmente colapsa e se danifica. A presença de corpúsculos de Woronin foi analisada nas hifas de $P$. janczewskii crescido em sacarose e inulina. Nenhuma diferença significativa foi observada no número, localização, tamanho e forma dos corpúsculos de Woronin e na obstrução dos poros dos septos nas culturas do fungo crescido nas duas diferentes fontes de carbono. Os resultados obtidos indicam que a presença dos corpúsculos de Woronin em $P$. janczewskii não pode ser associada com a presença de hifas mais facilmente danificadas, embora a função dessas organelas na obstrução dos poros dos septos tenha sido confirmada.

Palavras-chave: corpúsculos de Woronin, Penicillium, inulina, sacarose. 


\section{REFERENCES}

1. Collinge, A.J.; Markham, P. Ultrastructure of hyphal tip bursting in Penicillium chrysogenum. FEMS Microbiol. Lett., 91: 49-54, 1992.

2. Cordeiro Neto, F.; Pessoni, R.A.B.; Figueiredo-Ribeiro, R.C.L. Fungos produtores de inulinases isolados da rizosfera de asteráceas herbáceas do cerrado. Rev. Bras. Ci. Solo, 21: 149-153, 1997.

3. Jedd, G.; Chua, N. A new self-assembled peroxisomal vesicle required for efficient resealing of the plasma membrane. Nat. Cell. Biol., 2: 226-231, 2000

4. Larrondo, J.V.; Calvo, M.A. Woronin bodies in Arthrinium genus. Mycopathologia, 119: 157-160, 1992.

5. Markham, P. Occlusions of septal pores in filamentous fungi. Mycol. Res., 98: 1089-1106, 1994.
6. Pandey, A.; Soccol, C.R.; Selvakumar, P.; Soccol, V.T.; Krieger, N.; Fontana, J.D. Recent developments in microbial inulinases. App. Biochem. Biotechnol., 81: 35-52, 1999.

7. Pessoni, R.A.B.; Figueiredo-Ribeiro, R.C.L.; Braga, M.R. Extracellular inulinases from Penicillium janczewskii, a fungus isolated from the rhizosphere of Vernonia herbacea (Asteraceae). J. App. Microbiol., 86: 141-147, 1999.

8. Reynolds, E.S. The use of lead citrate at high $\mathrm{pH}$ as an electron-opaque stain in electron microscopy. J. Cell. Biol., 17: 208-212, 1963.

9. Rowley, J.C. III; Moran, D.T. A simple procedure for mounting wrinkle-free sections on Formvar-coated slot grids. Ultramicroscopy., 1: 151-155, 1975.

10. Turnau, K.; Kottke, I.; Oberwinkler, F. Comparative study of elongated and globose Woronin bodies using electron energy loss spectroscopy (EELS) and imaging (ESI). Mycol. Res., 97: 14991504, 1993. 